Ambiente \& Água - An Interdisciplinary Journal of Applied Science
ISSN 1980-993X - doi:10.4136/1980-993X
www.ambi-agua.net
E-mail: ambi.agua@gmail.com

\title{
Estimation of corrosive and scaling trend in drinking water systems in the city of Azogues, Ecuador
}

\author{
ARTICLES doi:10.4136/ambi-agua.2237
}

Received: 05 Feb. 2018; Accepted: 20 Aug. 2018

\author{
Fernando García-Ávila ${ }^{1,2 *}$; Lía Ramos-Fernández³ ${ }^{3}$ César Zhindón-Arévalo ${ }^{4}$ \\ ${ }^{1}$ Universidad de Cuenca, Cuenca, Ecuador \\ Facultad de Ciencias Químicas. E-mail: garcia10f@ hotmail.com \\ ${ }^{2}$ Universidad Nacional Agraria La Molina, La Molina, Lima, Peru \\ E-mail: garcia10f@ hotmail.com \\ ${ }^{3}$ Universidad Nacional Agraria La Molina, La Molina, Lima, Peru \\ Departamento Académico de Recursos Hídricos. E-mail: liaseptiembre2012@ hotmail.es \\ ${ }^{4}$ Universidad Católica de Cuenca, Azogues, Ecuador \\ Unidad Académica de Salud y Bienestar. E-mail: cezhindona@ucacue.edu.ec \\ *Corresponding author
}

\begin{abstract}
The quality of drinking water flowing in a distribution network can possess corrosive characteristics that may cause the material degradation of pipes and accessories. This problem can result in reduction of the service life of pipes and create a major public health problem. The agreement between the physical-chemical water quality analysis and national standards are not enough to confirm the balance of the water quality in terms of corrosion. In order to predict pipe corrosion in water distribution system networks, the corrosive trend was evaluated using the Langelier (LSI), Ryznar (RSI), and Larson-Skold (LRI) indexes based on measurements of $\mathrm{pH}$, temperature, total dissolved solids, alkalinity, calcium hardness, sulfate and chloride. This study was setup with 180 samples collected in six zones of the distribution network, from July to December of 2017, according to the standard methods for the analysis of drinking water. The results indicate a variation of the LSI from -1.22 to -1.68 ; RSI from 9.75 to 10.52 and LRI from 0.46 to 0.77 . A linear model was fitted for each index to predict the corrosion with the water quality conditions of this study case. Therefore, the drinking water of the city of Azogues, Ecuador has a corrosive tendency from significant to severe. Corrosion indices were calculated to provide useful information on the water's corrosiveness. These results indicate the need to constantly monitor the corrosion rate in the distribution network and conduct a laboratory study to adjust effective parameters such as $\mathrm{pH}$, in order to control corrosion.
\end{abstract}

Keywords: Azogues city, corrosion rates, potabilization, water quality.

\section{Estimativa da tendência corrosiva e de escala no sistema de água potável}

\section{RESUMO}

A qualidade da água potável que flui em uma rede de distribuição pode fornecer características corrosivas que podem causar a degradação do material de tubos e acessórios. Esse problema pode resultar na redução da vida útil dos tubos e em um grande problema de 
saúde pública. $\mathrm{O}$ acordo entre a análise físico-química da qualidade da água e os padrões nacionais não são suficientes para confirmar o equilíbrio da qualidade da água em termos de corrosão. Para prever a corrosão da tubulação nas redes do sistema de distribuição de água, a tendência corrosiva foi avaliada utilizando os índices Langelier (LSI), Ryznar (RSI) e LarsonSkold (LRI) com base em medidas de $\mathrm{pH}$, temperatura, sólidos dissolvidos totais, alcalinidade, dureza de cálcio, sulfato e cloreto. Este estudo foi montado com 180 amostras coletadas em seis zonas da rede de distribuição, de julho a dezembro de 2017, de acordo com os métodos padronizados de análise de água potável. Os resultados obtidos indicam uma variação do LSI de -1,22 para -1,68; RSI de 9,75 a 10,52 e LRI de 0,46 a 0,77. Um modelo linear foi montado para cada índice para prever a corrosão com as condições de qualidade da água do presente estudo. Portanto, a água potável da cidade de Azogues (Equador) tem uma tendência corrosiva de significativa a severa. Os índices de corrosão foram calculados para fornecer informações úteis sobre a corrosividade da água. Esses resultados indicam a necessidade de monitorar constantemente a taxa de corrosão na rede de distribuição e realizar um estudo de laboratório para ajustar parâmetros efetivos como o pH, a fim de controlar a corrosão.

Palavras-chave: cidade de Azogues, potabilização, qualidade da água, taxas de corrosão.

\section{INTRODUCTION}

Guaranteeing the availability and sustainable management of drinking water in compliance with regulatory requirements will increase consumer confidence (Omaka et al., 2015; Sorlini et al., 2017; Collivignarelli, 2017). Drinking water causes corrosion in the pipes used for transport (Gholizadeh et al., 2017). Iron pipes that undergo a corrosion process could have a great impact on the water quality distributed in the supply network (Yang et al., 2012). The corrosion process in the pipes is related to several factors, such as the pipe material, water quality and hydraulic conditions (García-Avila et al., 2018). The effect of the different water quality parameters including $\mathrm{pH}$, residual chlorine, total organic carbon, conductivity, dissolved oxygen, hardness and alkalinity influences corrosion and the formation of scale inside the metallic pipe (Cui et al., 2016). Vazdirvanidis et al. (2016) noted that the accelerated corrosion of parts of a water pump was probably caused by the presence of sulfates, sulfides and chlorides that caused a severe chemical attack on the various metallic components of the pump. Drinking water is commonly corrosive at a $\mathrm{pH}$ of 6.5 to 7.5 and with a low alkalinity. The corrosion potential of iron is affected by sulfate and chloride concentrations, which is why, as a consequence, chemical and physical differences are considered to alter water stability (Jazdzewska et al., 2016). Bigoni et al. (2014) indicated that the turbidity and iron concentration increase the corrosion of the pipes in the drinking water distribution network in a rural hospital in Peru. Corrosion of pipes and fittings that transport potable water is becoming a problem due to the high costs of repair and replacement (Liu et al., 2017). This means that it is important to know the physical and chemical characteristics of drinking water to determine the probable existence of corrosion using the Langelier saturation index (LSI), Ryznar stability index (RSI), the Larson-Skold index (LRI) (Achari et al., 2017).

Based on the LSI, 71\% of the waters of the city of Shiraz, Iran is causing incrustation. Based on the RSI, all the zones lacked the characteristic of formation of incrustations' According to the LRI, 29\% of the city have formations of inlays (Tavanpour et al., 2016). Considering the economic cost and the health risks related to incrustation and corrosion; the corrosive or fouling tendency can be analyzed using the indirect methods shown in Table 1. The equations of this table have been used to calculate the LSI (Liang et al., 2013; Alsaqqar et al., 2014; Choi et al., 2015; Vazdirvanidis et al., 2016; Gholizadeh et al., 2017); the RSI (Alsaqqar et al., 2014; Vazdirvanidis et al., 2016; Achari et al., 2017); and the LRI (Mirzabeygi 
et al., 2017; Peng et al., 2013; Alsaqqar et al., 2014; Zhang et al., 2014).

Taking into account the corrosion problems caused in drinking water pipes and the lack of studies on the drinking water distribution network of the city of Azogues, Ecuador, this research was carried out to determine the corrosion/incrustations in the pipes of the different zones. The results provided information on the chemical behavior of inorganic contaminants in water and its influence on drinking water quality.

\section{MATERIALS AND METHODS}

\subsection{Description of the study area}

The drinking water distribution network on which this study was conducted is located in the city of Azogues, which is located in the southern part of the Ecuadorian Republic. Its geographical coordinates are: latitude $2^{\circ} 44^{\prime} 22^{\prime \prime} \mathrm{S}$, longitude: 78 $50^{\prime} 54^{\prime \prime}$, and cover approximately $1200 \mathrm{~km}^{2}$. The average altitude of the town is 2518 meters above sea level. The city has a population of 70,064 inhabitants. Its average temperature is $17^{\circ} \mathrm{C}$; about 42,071 inhabitants receive water from the public network. There are no relevant studies on the corrosion that water can cause in the pipes and fittings of both the public and private networks. Figure 1 shows the location of the network supply, which is made up of pipes with diameters between 315 and $32 \mathrm{~mm}$. The total length of the supply line is $218,105 \mathrm{~m}$. A number of 288 valves have been installed. there are 26 reserves, distributed in six zones. Ten of the reserves have a capacity between 250 and $1000 \mathrm{~m}^{3}$. The altimetric variation of whole network is 2390-2823 meters above sea level.
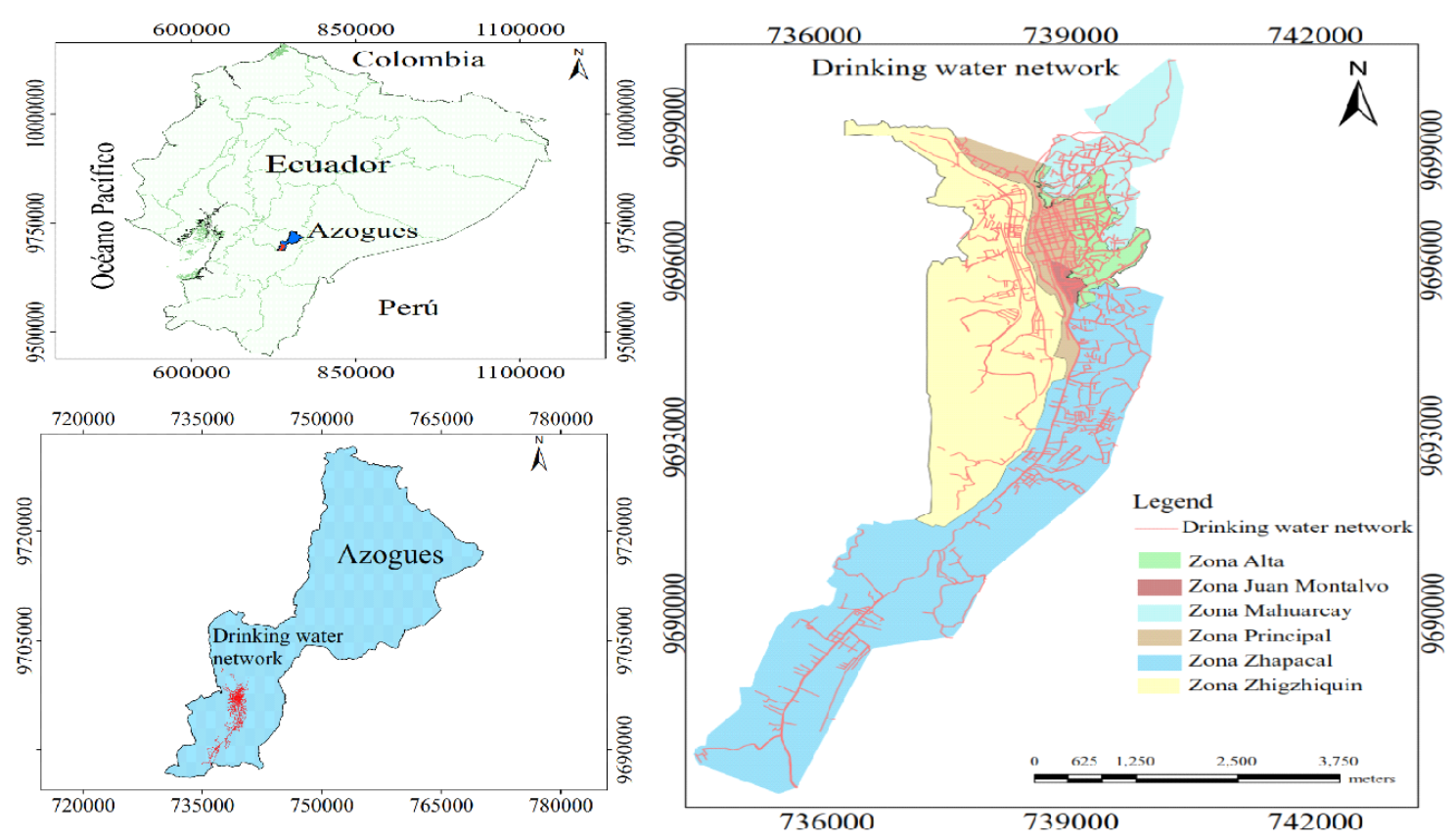

Figure 1. Location of the study area.

\subsection{Sampling and analysis of water}

To examine the conditions of corrosion and scale formation in the water distribution network of Azogues, 30 samples were taken monthly. A total of 180 drinking water samples were taken over six months at 30 sampling points; the sampling points were located in the drinking water distribution network taking into account the length of the distribution network, the location of the reserve tanks and the number of users present in each of the six zones. The sampling and analyses were carried out from July to December. All the samples were collected in polyethylene 1-liter containers complying with the necessary requirements to not alter the

\section{IPABH}


samples for later analysis. The samples were obtained from the faucets in kitchens and bathrooms of homes, commercial places such as restaurants, workshops, washing cars, shops, etc., as well as from distribution tanks. The samples were maintained at $4{ }^{\circ} \mathrm{C}$ and were transported on the same day for analysis to the laboratory of the city's municipal drinking water company. The tests on all water samples were analyzed according to the Standard Methods for the examination of water and wastewater (Apha et al., 2012). The calcium hardness and alkalinity were measured by the titration method; the concentration of hydrogen ions $(\mathrm{pH})$, total dissolved solids (TDS) and temperature were measured with the Hach Multiparameter HQ 40d; chloride and sulfate were determined with the HACH DR 2500 Spectrophotometer and compared with national standards. The $\mathrm{pH}$, TDS and temperature were determined in site.

\subsection{Determination of corrosion and scaling trend in drinking water}

The LSI, RSI and LRI were calculated using the corresponding equations in Table 1 . These indices allow the evaluation of the corrosion potential of the pipeline for each point of the network once the physical-chemical analysis has been realized (Bigoni et al., 2014).

Table 1. Description of corrosion indexes used in this study.

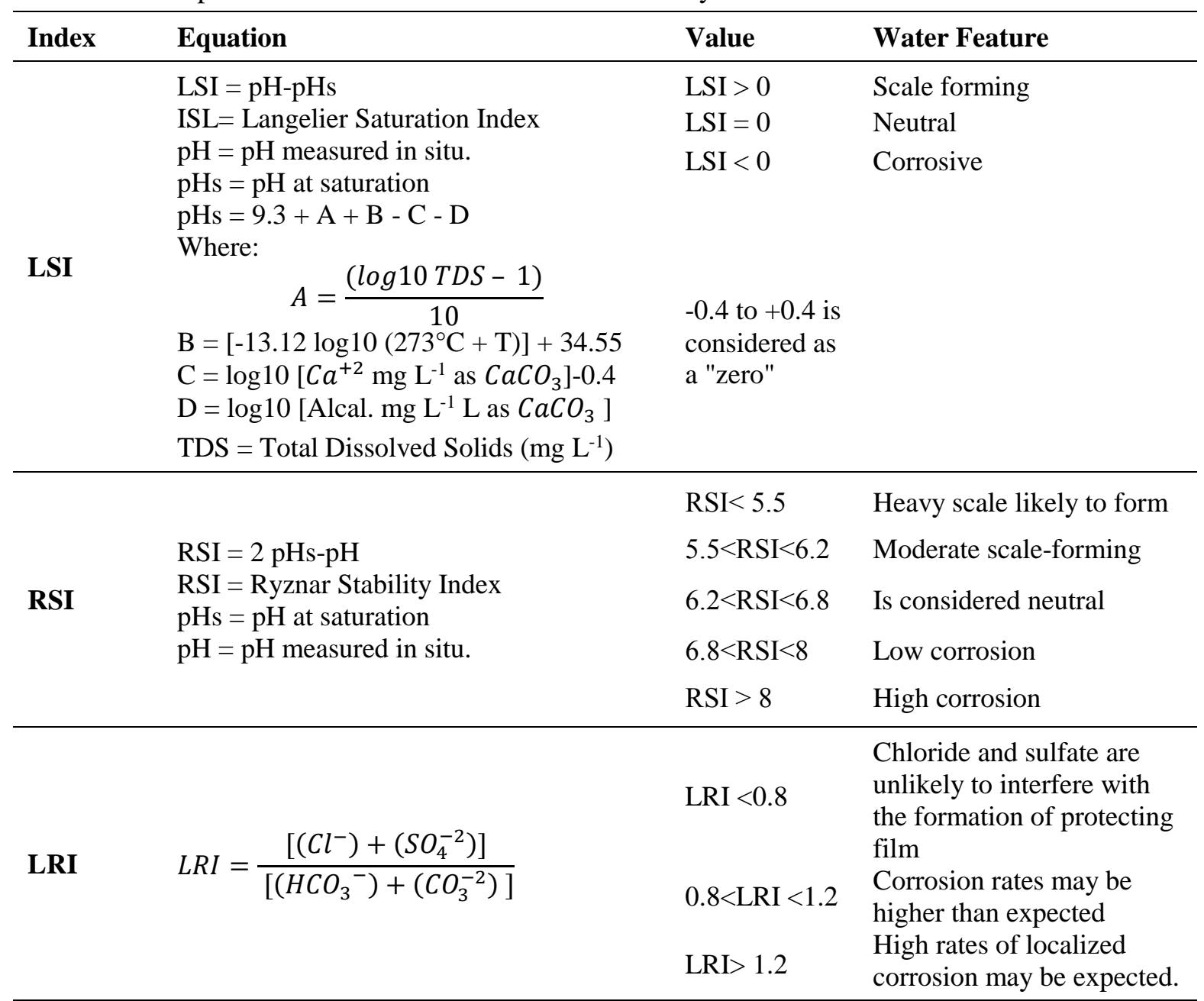

Source: Alsaqqar et al. (2014); Tavanpour et al. (2016); Mirzabeygi et al. (2017). 


\section{RESULTS AND DISCUSSION}

\subsection{Physical and chemical characteristics}

Table 2 shows the average values of temperature, $\mathrm{pH}$, total dissolved solids (TDS), the calcium hardness, alkalinity, chlorides, sulfates and free chlorine of the 180 samples collected at the 30 sites monitored over six months. Figure 2 shows the variation of the physical-chemical parameters of drinking water obtained at each of the sampling points.

When analyzing the $\mathrm{pH}$ values of both Table 2 and Figure 2, conditions observed are almost neutral at each sampling point and during all the months analyzed. In terms of quality of drinking water according to the Ecuadorian standard, the recommended established value is a minimum $\mathrm{pH}$ of 6.5 and a maximum of 8.5. While the waters evaluated are within the acceptable range with values between 6.87 and 7.75 , certain samples presented a $\mathrm{pH}$ less than 7 and were taken in the month of July. This slightly acidic condition can accelerate corrosive processes; this $\mathrm{pH}$ record is due to a contribution from natural processes. For its part, the temperature of water presented values near the ambient temperature for all samples; the temperature varied between 12.4 and $24.8^{\circ} \mathrm{C}$. The low temperatures that mostly correspond to the months of July, August and September indicate that there is a tendency to corrosion; there are no high temperatures that may cause the precipitation of calcium carbonate, which can cause scale in the pipes and therefore decrease the corrosion. Considering the average values of Figure 2 , it can be observed that the temperature values varies according the month, so the lowest temperatures are presented in the months of July and August, while the highest temperatures are presented in the months of October, November and December.

To determine the corrosive or scaling character of the water, it is also important to know the concentration of total dissolved solids (TDS). This parameter in the first instance provides an indicator of the quality of drinking water. Hence, when compared to the maximum permissible value of the Ecuadorian standard equivalent to $1000 \mathrm{mg} \mathrm{L}^{-1}$, it can be observed that the water distributed in Azogues presents values between 43.1 and $108.0 \mathrm{mg} \mathrm{L}^{-1}$, well below the established maximums. Even in spite of the low concentrations of TDS, it is important to note that the concentration of total dissolved solids in aqueous solutions is directly proportional to the conductivity, and its increase can favor the corrosive tendency.

When examining the values of drinking water hardness presented in Figure 2, according to the classification, it is observed that this water presents slightly hard values, which is especially related to low concentrations of calcium. This parameter is also an indicator of the quality of drinking water. Hence, when compared with the maximum permissible value of the Ecuadorian standard equivalent to $300 \mathrm{mg} \mathrm{L}^{-1}$, it can be observed that drinking water for the present study has values between 32.1 and $79.1 \mathrm{mg} \mathrm{L}^{-1}$, which are well below the established maximums. Waters with low hardness are considered aggressive, causing deterioration and corrosion in supply networks. This fact, together with the low $\mathrm{pH}$ presented at certain points, can generate a corrosive effect on the part of these waters.

Figure 2 shows that the alkalinity during the months of July to September has lower values compared to the months of October to December. This is due to the fact that during the months of July and August there are generally fewer rains that cause a decrease in alkalinity; in general there is a corrosive tendency caused by low alkalinity of water, which is at values lower than $76 \mathrm{mg} \mathrm{L}^{-1}$ as calcium carbonate. The Ecuadorian norm for concentrations of sulfate and chloride ions in drinking water establish maximum permissible values of $200 \mathrm{mg} \mathrm{L}^{-1}, 250 \mathrm{mg} \mathrm{L}^{-1}$, respectively. The average values found in the drinking water in the present study were $5.65 \mathrm{mg} \mathrm{L}^{-1}$ and $18.12 \mathrm{mg} \mathrm{L}^{-1}$, which are well below the established norm. Sulfate ions and chlorides are components of natural waters, which is why the presence of these ions and their low concentrations is justified. 
Table 2. Average values of the analysis of water collected in the sampling sites.

\begin{tabular}{|c|c|c|c|c|c|c|c|}
\hline $\begin{array}{c}\mathbf{N}^{\circ} \\
\text { Sample }\end{array}$ & pH & $\begin{array}{c}\text { Temperature } \\
{ }^{\circ} \mathrm{C}\end{array}$ & $\begin{array}{c}\text { TDS } \\
\text { mg } L^{-1}\end{array}$ & $\begin{array}{c}\text { Calcium } \\
\mathrm{mg} \mathrm{L}^{-1} \text { as } \\
\mathrm{CaCO}_{3}\end{array}$ & $\begin{array}{c}\text { Alkalinity } \\
\mathrm{mg} \mathrm{L}^{-1} \text { as } \\
\mathrm{CaCO}_{3}\end{array}$ & $\begin{array}{l}\text { Sulphate } \\
\text { mg L }^{-1}\end{array}$ & $\begin{array}{c}\text { Chloride } \\
\text { mg L }^{-1}\end{array}$ \\
\hline 1 & $7.42 \pm 0.07$ & $17.66 \pm 0.6$ & $81.17 \pm 7.02$ & $20.40 \pm 1.91$ & $46.83 \pm 6.30$ & $22.33 \pm 2.73$ & $5.30 \pm 0.47$ \\
\hline 2 & $7.38 \pm 0.08$ & $18.96 \pm 0.4$ & $82.17 \pm 5.33$ & $20.87 \pm 1.49$ & $50.00 \pm 6.32$ & $21.00 \pm 2.45$ & $5.58 \pm 0.55$ \\
\hline 3 & $7.2+0.06$ & $16.72 \pm 1.0$ & $63.67 \pm 4.54$ & $20.87 \pm 2.01$ & $51.33 \pm 5.33$ & $19.17 \pm 1.96$ & $5.33 \pm 0.59$ \\
\hline 4 & $7.17 \pm 0.05$ & $19.44 \pm 0.7$ & $80.67 \pm 7.82$ & $23.13 \pm 1.79$ & $48.67 \pm 5.81$ & $23.00 \pm 2.27$ & $5.22 \pm 0.54$ \\
\hline 5 & $7.41 \pm 0.12$ & $18.02 \pm 0.5$ & $71.50 \pm 6.48$ & $21.80 \pm 2.80$ & $46.67 \pm 6.27$ & $19.50 \pm 2.91$ & $5.05 \pm 0.96$ \\
\hline 6 & $7.23 \pm 0.07$ & $17.3 \pm 0.6$ & $70.50 \pm 5.16$ & $22.47 \pm 1.54$ & $52.50 \pm 5.90$ & $19.17 \pm 2.01$ & $5.12 \pm 0.57$ \\
\hline 7 & $7.2 \pm 0.06$ & $17.44 \pm 08$ & $72.33 \pm 6.01$ & $21.67 \pm 2.01$ & $52.5 \pm 6.05$ & $18.83 \pm 2.06$ & $11.58+0.6$ \\
\hline 8 & $7.18 \pm 0.06$ & $16.3 \pm 0.6$ & $72.33 \pm 4.24$ & $21.73 \pm 1.79$ & $53.67 \pm 5.65$ & $18.58 \pm 1.70$ & $4.57 \pm 1.05$ \\
\hline 9 & $7.2 \pm 0.05$ & $17.72 \pm 1.0$ & $64.50 \pm 5.91$ & $21.00 \pm 1.43$ & $49.50 \pm 5.14$ & $17.33 \pm 2.33$ & $5.38 \pm 0.71$ \\
\hline 10 & $7.22 \pm 0.05$ & $16.1 \pm 1.4$ & $66.33 \pm 4.76$ & $20.20 \pm 1.63$ & $50.50 \pm 6.04$ & $17.33 \pm 1.96$ & $5.70 \pm 0.48$ \\
\hline 11 & $7.16 \pm 0.05$ & $15.78 \pm 0.3$ & $72.67 \pm 6.50$ & $21.33 \pm 1.66$ & $51.00 \pm 4.92$ & $15.50 \pm 2.08$ & $5.58 \pm 0.97$ \\
\hline 12 & $7.26 \pm 0.05$ & $15.66 \pm 0.8$ & $68.83 \pm 4.69$ & $21.47 \pm 1.14$ & $53.67 \pm 6.06$ & $17.00 \pm 2.77$ & $4.95 \pm 0.6$ \\
\hline 13 & $7.11 \pm 0.08$ & $16.16 \pm 1.2$ & $60.00 \pm 3.66$ & $17.47 \pm 0.98$ & $40.67 \pm 2.53$ & $13.50 \pm 2.77$ & $7.27 \pm 1.56$ \\
\hline 14 & $7.25 \pm 0.10$ & $18.06 \pm 0.8$ & $70.00 \pm 5.66$ & $22.23 \pm 2.16$ & $47.00 \pm 6.47$ & $21.00 \pm 2.39$ & $5.30 \pm 0.41$ \\
\hline 15 & $7.3 \pm 0.08$ & $16.36 \pm 0.4$ & $70.33 \pm 6.54$ & $21.57 \pm 1.48$ & $48.67 \pm 4.98$ & $20.17 \pm 1.66$ & $5.67 \pm 0.46$ \\
\hline 16 & $7.17 \pm 0.06$ & $18.2 \pm 1.3$ & $72.67 \pm 7.29$ & $21.33 \pm 1.35$ & $45.67 \pm 4.90$ & $21.17 \pm 2.24$ & $5.22 \pm 0.4$ \\
\hline 17 & $7.21 \pm 0.07$ & $17.64 \pm 0.2$ & $69.83 \pm 5.55$ & $20.60 \pm 1.39$ & $46.00 \pm 4.50$ & $18.83 \pm 1.89$ & $5.62 \pm 0.74$ \\
\hline 18 & $7.24 \pm 0.06$ & $17.8 \pm 0.7$ & $68.67 \pm 6.99$ & $22.00 \pm 1.78$ & $48.83 \pm 5.08$ & $19.00 \pm 2.82$ & $5.58 \pm 0.4$ \\
\hline 19 & $7.23 \pm 0.09$ & $17.76 \pm 0.6$ & $71.00 \pm 6.04$ & $21.87 \pm 1.90$ & $47.50 \pm 5.66$ & $19.67 \pm 2.38$ & $5.58 \pm 0.65$ \\
\hline 20 & $7.18 \pm 0.06$ & $17.52 \pm 1.2$ & $69.67 \pm 7.22$ & $21.20 \pm 1.48$ & $46.52 \pm 4.27$ & $17.67 \pm 2.69$ & $5.57 \pm 0.61$ \\
\hline 21 & $7.22 \pm 0.06$ & $18.7 \pm 0.4$ & $58.17 \pm 2.33$ & $17.47 \pm 1.0$ & $40.82 \pm 1.87$ & $12.50 \pm 2.79$ & $6.63 \pm 1.03$ \\
\hline 22 & $7.24 \pm 0.04$ & $17.3 \pm 0.5$ & $63.50 \pm 4.92$ & $20.13 \pm 1.54$ & $46.50 \pm 4.15$ & $18.50 \pm 2.17$ & $5.72 \pm 0.80$ \\
\hline 23 & $7.24 \pm 0.09$ & $17.62 \pm 0.7$ & $68.17 \pm 5.13$ & $21.33 \pm 1.78$ & $49.17 \pm 5.24$ & $19.50 \pm 2.11$ & $5.47 \pm 0.47$ \\
\hline 24 & $7.26 \pm 0.07$ & $17.22 \pm 1.1$ & $66.83 \pm 6.77$ & $21.07 \pm 1.73$ & $47.50 \pm 2.96$ & $17.50 \pm 2.62$ & $5.80 \pm 0.58$ \\
\hline 25 & $7.2 \pm 0.05$ & $17.1 \pm 0.7$ & $64.33 \pm 3.8$ & $20.07 \pm 1.56$ & $46.33 \pm 3.48$ & $17.00 \pm 2.28$ & $5.30 \pm 0.82$ \\
\hline 26 & $7.26 \pm 0.09$ & $18.1 \pm 0.6$ & $67.83 \pm 5.15$ & $20.67 \pm 1.37$ & $48.83 \pm 4.43$ & $16.33 \pm 2.33$ & $5.88 \pm 0.74$ \\
\hline 27 & $7.28 \pm 0.07$ & $16.24 \pm 1.1$ & $65.17 \pm 6.99$ & $20.13 \pm 1.54$ & $47.67 \pm 4.72$ & $15.83 \pm 2.21$ & $6.03 \pm 0.68$ \\
\hline 28 & $7.31 \pm 0.06$ & $17.16 \pm 1.2$ & $67.83 \pm 5.70$ & $20.2 \pm 1.51$ & $51.33 \pm 4.72$ & $17.33 \pm 2.17$ & $6.00 \pm 0.86$ \\
\hline 29 & $7.26 \pm 0.05$ & $18.56 \pm 0.8$ & $72.50 \pm 6.84$ & $20.13 \pm 1.43$ & $49.00 \pm 5.49$ & $16.17 \pm 2.70$ & $5.93 \pm 0.67$ \\
\hline 30 & $7.27 \pm 0.06$ & $17.26 \pm 1.2$ & $59.83 \pm 2.64$ & $17.33 \pm 0.91$ & $40.00 \pm 2.54$ & $14.00 \pm 3.2$ & $5.97 \pm 1.22$ \\
\hline
\end{tabular}



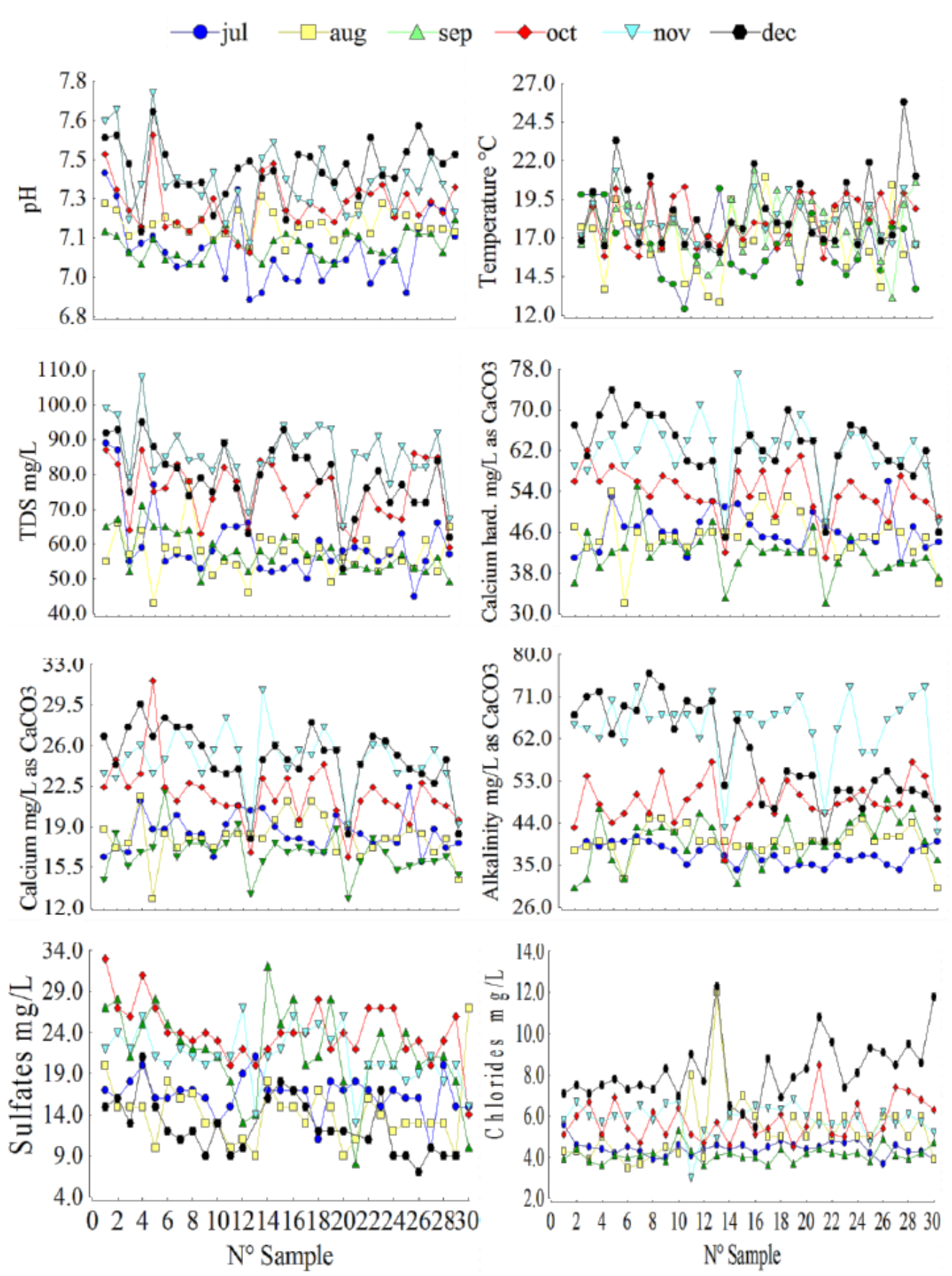

Figure 2. Variation of $\mathrm{pH}$, temperature, TDS, calcium, alkalinity, sulfates and chlorides of drinking water in the distribution network sampling points.

\subsection{Corrosion monitoring}

Table 3 presents the mean values of the indices obtained by zones of the supply network. The table shows that the values of the indices are similar in each of the zones. All values obtained for the LSI are negative, with an average value of 1.39 (Table 3 and Figure 3), indicating that the water that is distributed in all zones of Azogues is corrosive, considering that at more negative values there is greater corrosivity. The values in Table 3 show that the zones Zhigzhiquin and Zhapacal (2390-2500 altitude meters above sea level) have less negative values with respect to the Mahuarcay zone (altitude 2700-2823 meters above sea level); this could be due to the temperature variation, which in turn affects the $\mathrm{pH}$.

The values obtained with the RSI turned out to be greater than nine, indicating that the water that is distributed in Azogues is very corrosive. It can be seen that the LRI average value

\section{IPABH}


of 10.07 shows a slightly to moderately corrosive character of the drinking water distributed in Azogues. Meanwhile, average LRI values of 0.58 were obtained, which does not conform with the strongly corrosive character determined by the Langelier and Ryznar models. This difference is because the Larson-Skold relationship is based on the corrosive influence of the chloride, sulfate and bicarbonate ion, not considering other physicochemical factors such as $\mathrm{pH}$, temperature, total dissolved solids, alkalinity and calcium.

Table 3. Average values of corrosion indexes by zones.

\begin{tabular}{lccc}
\hline Zone & LSI & RSI & LRI \\
\hline Alta & -1.40 & 10.03 & 0.52 \\
Mahuarcay & -1.58 & 10.38 & 0.53 \\
Media & -1.4 & 10.03 & 0.67 \\
Zhigzhiquin & -1.31 & 9.94 & 0.63 \\
Principal & -1.43 & 10.09 & 0.54 \\
Zhapacal & -1.34 & 9.93 & 0.60 \\
\hline Average & $\mathbf{- 1 . 3 9}$ & $\mathbf{1 0 . 0 7}$ & $\mathbf{0 . 5 8}$ \\
p & $<0.0001$ & $<0.0001$ & $<0.0001$ \\
\hline
\end{tabular}

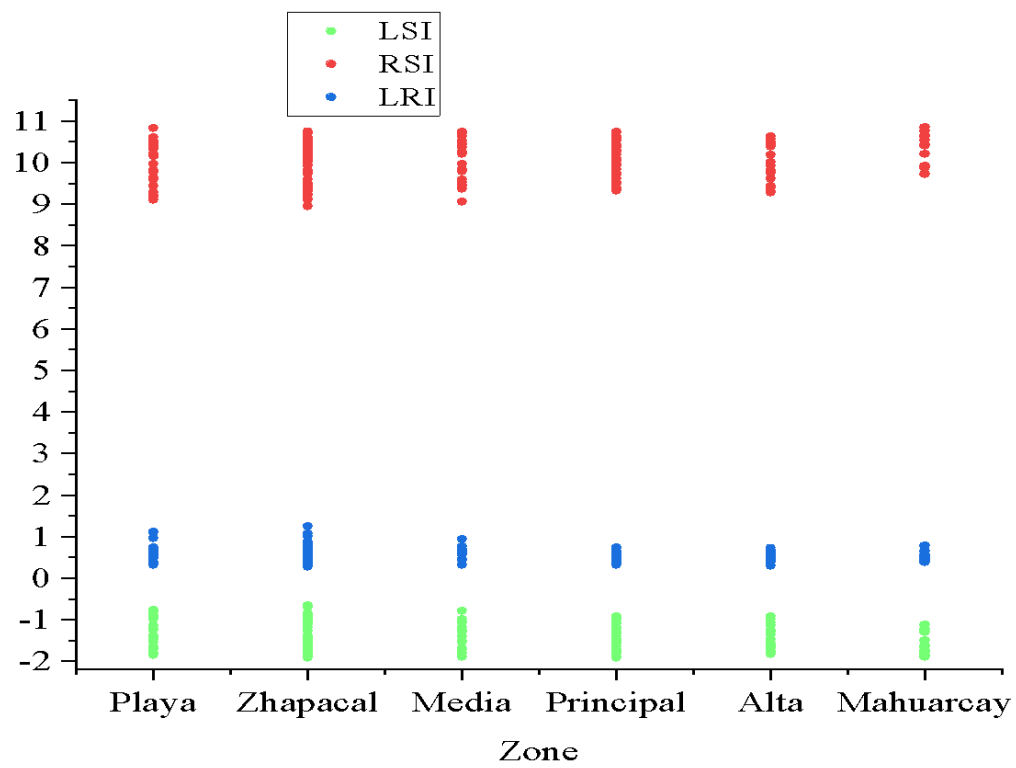

Figure 3. Variation of corrosion indexes in the different zones.

The results obtained by several authors are presented in Table 4 . When compared with the results obtained in this study, we can observe a similarity to the results obtained by Alimoradi et al. (2018) and Khorsandi et al. (2015). These waters are highly corrosive based on the LSI, RSI and LRI; but they have no tendency to form coatings of calcium carbonate precipitates, due to the low alkalinity and hardness.

Table 4. Average values of LSI, RSI, LRI obtained by several authors.

\begin{tabular}{lccc}
\hline Authors & LSI & RSI & LRI \\
\hline Abbasnia et al. (2018) & 0.5 & 6.76 & 2.71 \\
Yousefi et al. (2018) & 1.15 & 6.92 & 0.85 \\
Alimoradi et al. (2018) & -1.31 & 9.73 & 0.24 \\
Khorsandi et al. (2015) & -1.94 & 12.05 & 0.68 \\
Tavanpour et al. (2016) & 0.08 & 7.15 & 1.1 \\
\hline
\end{tabular}


Figure 4 shows the variation of corrosion indexes with physical-chemical parameters. $\mathrm{pH}$ is one of the main factors that influence the corrosion process (Cui et al., 2016). In Table 2 and Figure 2, it can be observed that the $\mathrm{pH}$ varied between 6.87 and 7.75, with an average of 7.24. In Figure 4(a) it can be seen that the LSI increases with increasing pH; meanwhile, the RSI decreased with the increase of $\mathrm{pH}$. Therefore, corrosion increases with the decrease in $\mathrm{pH}$. Another factor that alters the corrosion process is temperature; increase in temperature can cause the precipitation of calcium carbonate, which can cause encrustation in the pipes and therefore reduce corrosion. In Table 2 and Figure 2, it can be observed that the temperature varied between 12.4 and $24.8^{\circ} \mathrm{C}$, with an average of $17.6^{\circ} \mathrm{C}$. In Figure $4(\mathrm{~b})$, it can be seen that the LSI increased with the temperature increase; meanwhile, the RSI decreased with temperature.

The conventional potabilization process does not affect the dissolved content of treated water. The effect of TDS content on the corrosivity of water is a complex issue; some substances such as carbonate and bicarbonate reduce corrosion, while chloride and sulfate ions notably accelerate corrosion (Alsaqqar et al., 2014). From the data registered in Table 2 and Figure 2, the TDS concentration fluctuated between 43.1 and $108.0 \mathrm{mg} \mathrm{L}^{-1}$ with an average of $69.29 \mathrm{mg} \mathrm{L}^{-1}$. In Figure 4(c) it can be seen that the LSI increased with the increase of the TDS. Meanwhile, the RSI was reduced with the increase of TDS; therefore the corrosion increases with the decrease of TDS. Calcium is the second most frequent component in most surface waters and is generally among the three or four most frequent ions in groundwater. The increase $\mathrm{Ca}^{2+}$ concentration decreases water corrosivity (Mirzabeygi et al., 2017), since $\mathrm{Ca}^{2+}$ is important for the formation of a passivation film on the surface of the pipe, decreasing corrosion. From the data recorded in Table 2 and Figure 2, the $\mathrm{Ca}^{2+}$ concentration varied between 12.8 and $31.6 \mathrm{mg} \mathrm{L}^{-1}$, with an average of $20.8 \mathrm{mg} \mathrm{L}^{-1}$. In Figure 4(d), it can be seen that the LSI increased with the calcium increase; the RSI decreased with the calcium increase. The slightly low calcium values in this study influenced the presence of drinking water corrosion.

In water treatment plants, alkalinity is required in the coagulation process for the reaction of alum with water; lime can be added if natural alkalinity is not sufficient for this reaction. Water corrosivity increases as alkalinity decreases (Peng et al., 2013, Choi et al., 2015). According to data obtained from the water analysis, the variation in alkalinity ranged between 30.00 and $76.00 \mathrm{mg} \mathrm{L}^{-1}$, with an average of $48.42 \mathrm{mg} \mathrm{L}^{-1}$ as $\mathrm{CaCO}_{3}$, as shown in Table 2 and Figure 2. In Figure 4(e) it can be seen that the LSI increased with the increase in alkalinity; meanwhile, the RSI decreased with the increase in alkalinity. The somewhat low concentrations of alkalinity that have been obtained in this study favor the solubility of $\mathrm{CO}_{2}$, increasing the drinking water corrosivity; it can also be observed that alkalinity does not have a great relationship with the LRI.

The chloride and sulfate ions drastically reduce corrosion resistance (Vazdirvanidis et al., 2016; Yang et al., 2012). Steel is easily susceptible to pitting corrosion in solutions containing aerated chloride with $\mathrm{pH}$ in a wide range $(4-12.5)$ at room temperature (Wang et al., 2015). According to data obtained from the water analysis, the chloride ion concentration fluctuated between 1.30 and $12.30 \mathrm{mg} \mathrm{L}^{-1}$, with an average of $5.65 \mathrm{mg} \mathrm{L}^{-1}$; the sulfate varied between 3.0 and $33.0 \mathrm{mg} \mathrm{L}^{-1}$ with an average of $18.12 \mathrm{mg} \mathrm{L}^{-1}$, as shown in Table 2 and Figure 2. In Figure 4(f), it can be seen that the LRI increases with the increase of the concentration of the sulfate ion; the LRI does not show a direct relationship with the chloride ion concentration. Hence, according to the LRI values obtained in this study, there is a slight corrosion of drinking water.

A box plot was made using the monthly results for each of the indices. For the LSI, Figure 5(a) shows that during the first three months of monitoring (July-September) values are observed between -1.40 and -2.00 , indicating a strong corrosion. This is due to the fact that in these months the ambient temperature and therefore of the water is low with respect to that registered during the year. In the same way, the alkalinity and $\mathrm{pH}$ were slightly low from July

\section{IPABH}

Rev. Ambient. Água vol. 13 n. 5, e2237 - Taubaté 2018 
to September, which increased the corrosion. From October to December, a decrease of -1.40 to -0.80 can be observed in the LSI, generating a less corrosive tendency than during the three previous months.

Analyzing the box plot for the RSI, Figure 5(b) shows that during the first three months of sampling (July-September) values between 10.00 and 11.00 are observed, due to a significant decrease in terms of the temperature, $\mathrm{pH}$ and alkalinity. During the following three months a decrease in the index of 10.00 to 9.00 can be observed, decreasing this index, but retaining its severe corrosive character.
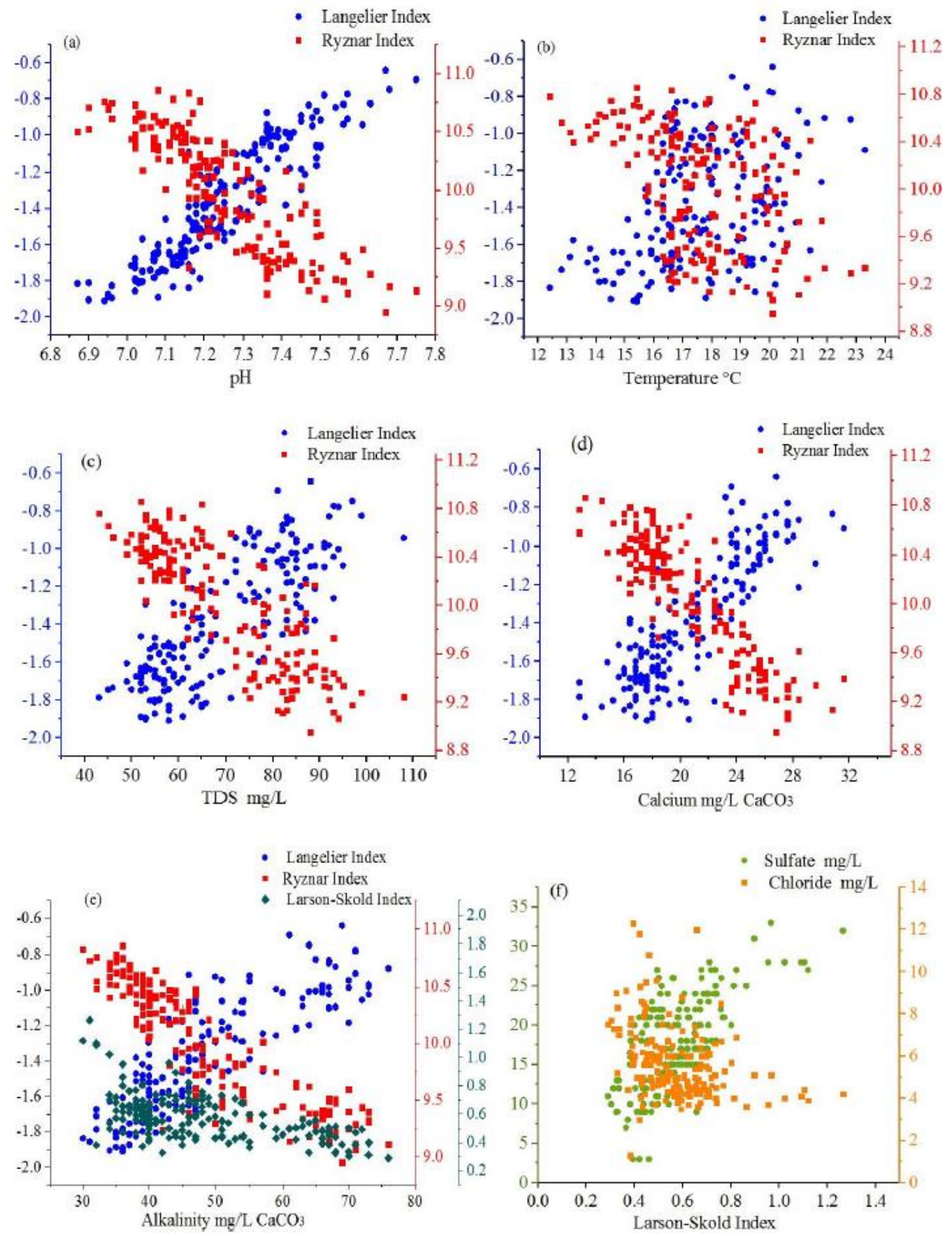

Figure 4. Variation of corrosion indexes with physical-chemical parameters. (a) $\mathrm{pH}$ relationship with LSI and RSI; (b) temperature relationship with LSI and RSI; (c) TDS relationship with LSI and RSI; (d) calcium relationship with LSI and RSI; (e) alkalinity relationship with LSI, RSI and LRI; (f) LRI relationship with sulfates and chlorides. 
In Figure 5(c), we can observe a constant trend regarding the LRI; the values calculated and analyzed during July - December, are between the range of 0.29 to 1.26 , with an average value of 0.56 , presenting a slight corrosion, with a slightly corrosive character, which indicates that there is little amount of chloride and sulfate ions that can cause corrosivity.
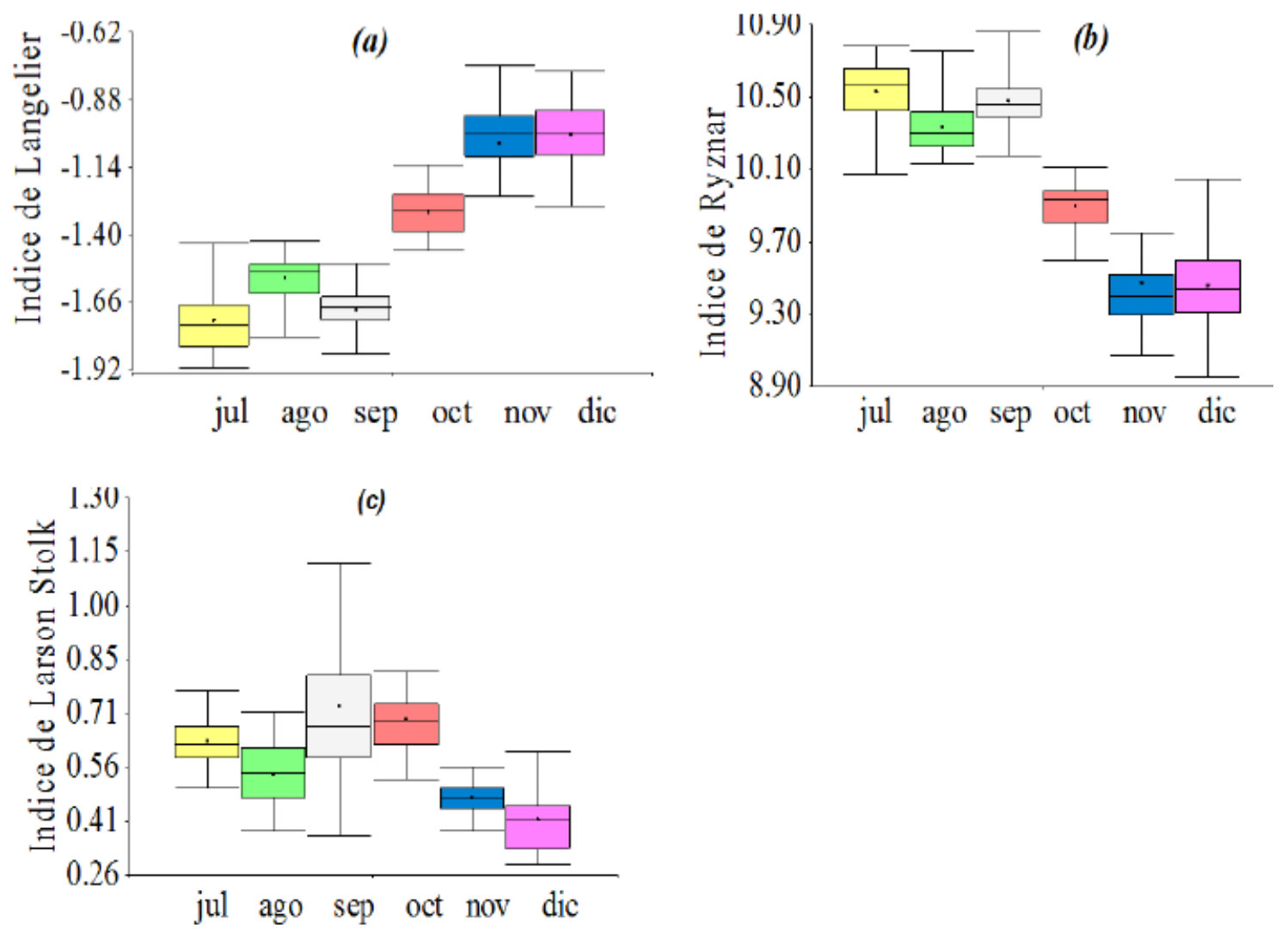

Figure 5. Variation of corrosion indexes over time. (a) Variation of LSI with months, (b) Variation of RSI with months, (c) Variation of LRI with months.

\subsection{Linear model for corrosion indexes}

To facilitate the calculation of corrosion in the drinking water distribution network in Azogues, a mathematical model was obtained for each of the corrosion indexes analyzed in this study. The multiple regression technique was applied using Infostat software, based on data of $\mathrm{pH}$, temperature, SDT, alkalinity, calcium, sulfates and chlorides, obtained from drinking water sampling and analysis. The results of the multiple regression for LSI are presented in Table 5.

Table 5. Regression coefficients and statistical data associated with the LSI model.

\begin{tabular}{lcccccccc}
\hline Coef & Est. & E.E. & LI (95\%) & LS (95\%) & T & P-Value & CpMallows & VIF \\
\hline Const & -9.84 & 0.06 & -9.96 & -9.71 & -155.32 & $<0.0001$ & & \\
PH & 1.01 & 0.01 & 0.99 & 1.03 & 106.29 & $<0.0001$ & 11236.03 & 1.96 \\
T & 0.02 & $6.60 \mathrm{E}-04$ & 0.02 & 0.02 & 28.91 & $<0.0001$ & 836.03 & 1.36 \\
SDT & $-4.30 \mathrm{E}-04$ & $1.60 \mathrm{E}-04$ & $-7.50 \mathrm{E}-04$ & $-1.20 \mathrm{E}-04$ & -2.69 & 0,008 & 12.18 & 3.91 \\
Calcium & 0.02 & $5.50 \mathrm{E}-04$ & 0.02 & 0.02 & 38.61 & $<0.0001$ & 1487.2 & 3.42 \\
Alkalinity & 0.01 & $1.80 \mathrm{E}-04$ & 0.01 & 0.01 & 44.71 & $<0.0001$ & 1992.51 & 3.49 \\
\hline
\end{tabular}

It can be observed that the $\mathrm{pH}$, temperature, TDS, calcium and alkalinity showed a value $\mathrm{p}<0.05$, there being a significant linear relationship with the LSI. The model obtained for the LSI is (Equation 1):

$$
L S I=-9.95+1.03 p H+0.02 T-0.00049 S D T+0.02 \text { Calcium }+0.01 \text { Alkalinity }
$$

\section{IPABH}


The equation is useful to calculate the LSI knowing the values of $\mathrm{pH}$, temperature in ${ }^{\circ} \mathrm{C}$, SDT in $\mathrm{mg} / \mathrm{L}$, calcium hardness in and alkalinity in $\mathrm{mg} / \mathrm{L}$ as $\mathrm{CaCO}_{3}$.

The results of the multiple regression for RSI are presented in Table 6. It can also be noted that the $\mathrm{pH}, \mathrm{T}, \mathrm{SDT}$, calcium and alkalinity showed a value $\mathrm{p}<0.05$, there being also a significant linear relationship with the RSI. The model obtained for the RSI is (Equation 2):

$R S I=19.93-1.06 p H-0.04 T+0.00096 S D T-0.04$ Calcium -0.02 Alkalinity

Table 6. Regression coefficients and statistical data associated with the RSI model.

\begin{tabular}{lcccccccc}
\hline Coef & Est. & E.E. & LI (95\%) & LS (95\%) & T & P-Value & CpMallows & VIF \\
\hline Const & 19.7 & 0.12 & 13.67 & 19.95 & 157.76 & $<0.0001$ & & \\
PH & -1.02 & 0.02 & -1.06 & -0.99 & -54.61 & $<0.0001$ & 2969.87 & 1.96 \\
T & -0.04 & $1.30 \mathrm{E}-03$ & -0.04 & -0.04 & -29.55 & $<0.0001$ & 873.33 & 1.36 \\
SDT & $8.40 \mathrm{E}-04$ & $3.20 \mathrm{E}-04$ & $2.10 \mathrm{E}-04$ & $1.50 \mathrm{E}-03$ & 2.64 & 0.0091 & 11.94 & 3.91 \\
Calcium & -0.04 & $1.10 \mathrm{E}-03$ & -0.04 & -0.04 & -39.07 & $<0.0001$ & 1522.9 & 3.42 \\
Alkalinity & -0.02 & $3.60 \mathrm{E}-04$ & -0.02 & -0.02 & -45.06 & $<0.0001$ & 2023.09 & 3.49 \\
\hline
\end{tabular}

\section{CONCLUSIONS}

Although the temperature values, total dissolved solids, alkalinity, calcium hardness, sulfate and chloride obtained in this study were admissible based on Ecuadorian regulations, the average values of the corrosion indexes obtained in this study indicated a significant corrosive tendency. The results obtained were: LSI: -1.39 ; RSI: 10.02 and LRI: 0.58 . These indicated a significant corrosive tendency of the drinking water distributed in Azogues. The most critical parameter analyzed for the LSI and RSI is $\mathrm{pH}$, as well as the low alkalinity and low hardness; while, for the Larson-Stolk index, the most critical parameter is sulfate. It can be concluded that an understanding of the chemical composition of drinking water is vital for predicting the materials behavior that are in contact with drinking water. The corrosion calculation caused by the water is based solely on the physical chemical parameters proposed by Langelier, Ryznar and Larson-Skold; this is not so exact, considering other factors or conditions that prevail in a typical drinking water network, such as dissolved oxygen, residual chlorine and room temperature. the supply system. This factor should be taken into account for the control and prevention of corrosion potential; adjustments in stabilization should be made at the treatment plant.

\section{ACKNOWLEDGEMENTS}

Fernando García developed this project with his own funds during his doctoral studies in Engineering and Environmental Sciences. The authors thank Eng. Xavier Ramírez, the manager of EMAPAL EP, for his support of this study. We also thank Damián Pauta and Diego Quezada, who helped with the monitoring campaign described, and Lcda Lucy Timbe for his help in translating the document.

\section{REFERENCES}

ABBASNIA, A.; ALIMOHAMMADI, M.; MAHVIA, A. H.; NABIZADEH, R.; YOUSEFI, M.; MOHAMMADI, A. A. et al. Assessment of groundwater quality and evaluation of scaling and corrosiveness potential of drinking water samples in villages of Chabahr city, Sistan and Baluchistan province in Iran. Data Brief, v. 16, p. 182-192, 2018. https://doi.org/10.1016/j.dib.2017.11.003 
ACHARI, V. S.; DEEPA, P.; AMBILI, M. S.; GEORGE, T. R. Corrosion Indices, Drinking and Irrigation Water Quality of Andhakaranazhy and Cherai Coastal Regions of Kerala. Academy of Chemistry Teachers, v. 3, n. 1, p. 10-14, 2017.

ALIMORADI, J.; NAGHIPOUR, D.; KAMANI, H. Data on corrosive water in the sources and distribution network of drinking water in north of Iran. Data Brief, v.17, p.105-118, 2018. https://doi.org/10.1016/j.dib.2017.12.057

ALSAQQAR, A.; KHUDAIR, B.; ALI, S. Evaluating Water Stability Indices from Water Treatment Plants in Baghdad City. Journal of Water Resource and Protection, v. 6, n. 14, p. 1344-1351, 2014. http://dx.doi.org/10.4236/jwarp.2014.614124

AMERICAN PUBLIC HEALTH ASSOCIATION - APHA; AMERICAN WATER WORKS ASSOCIATION - AWWA; WATER ENVIRONMENT FEDERATION - WEF. Standard Methods for examination of water and wastewater. Washington, DC, 2012.

BIGONI, R.; SORLINI, S.; COLLIVIGNARELlI, M. C.; BERBENNI, P. Drinking water quality assessment and corrosion mitigation in the hospital water supply system of Chacas village (Perú). Revista Ambiente \& Água, v. 9, n. 3, p. 379-389, 2014. http://dx.doi.org/10.4136/ambi-agua.1407

CHOI, J.; GYU, B.; HONG, S. Effects of NF treated water on corrosion of pipe distribution system and its implications to blending with conventionally treated water. Desalination, v. 360, p. 138-145, 2015. https://doi.org/10.1016/j.desal.2015.01.026

COLLIVIGNARELLI, C. Water safety: one of the primary objectives of our time. Revista Ambiente \& Água, v. 12, n. 1, p. 1-7, 2017. http://dx.doi.org/10.4136/ambi-agua.1994

CUI, Y.; LIU, S.; SMITH, K.; YU, K.; HU, H.; JIANG, W. Characterization of corrosion scale formed on stainless steel delivery pipe for reclaimed water treatment. Water Research, v. 88, p. 816-825, 2016. http://dx.doi.org/10.1016/j.watres.2015.11.021

GARCÍA-AVILA, F.; BONIFAZ-BARBA, G.; DONOSO-MOSCOSO, S.; FLORES DEL PINO, L.; RAMOS-FERNÁNDEZ, L. Dataset of copper pipes corrosion after exposure $\begin{array}{lllllll}\text { to chlorine. Data } & \text { Brief, } & \text { v. } 19, \quad \text { p. }\end{array}$ https://doi.org/10.1016/j.dib.2018.05.023

GHOLIZADEH, A.; MOKHTARI, M.; NAIMI, N.; SHIRAVANDC, B.; EHRAMPOUSHA, M. H.; MIRI, M. et al. Assessment of corrosion and scaling potential in groundwater resources; a case study of Yazd-Ardakan Plain , Iran. Groundwater for Sustainable Development, v. 5, p. 59-65, 2017. https://doi.org/10.1016/j.gsd.2017.04.002

JAZDZEWSKA, A.; DAROWICKI, K.; ORLIKOWSKI, J.; KRAKOWIAK, S.; ZAKOWSKI, K.; GRUSZKA, M. et al. Critical analysis of laboratory measurements and monitoring system of water-pipe network corrosion-case study. Case Studies in Construction Materials, v.4, p. 102-107, 2016. https://doi.org/10.1016/j.cscm.2016.01.004

KHORSANDI, H.; MOHAMMADI, A.; KARIMZADEH, S.; KHORSANDI, J. Evaluation of corrosion and scaling potential in rural water distribution network of Urmia, Iran. $\begin{array}{llllll}\text { Desalination and Water } & \text { Treatment, } & \text { p. } & 1-8, & \end{array}$ http://dx.doi.org/10.1080/19443994.2015.1042058

LIANG, J.; DENG, A.; XIE, R.; GOMEZ, M.; HU, J.; ZHANG, J. et al. Impact of flow rate on corrosion of cast iron and quality of re-mineralized seawater reverse osmosis (SWRO) membrane product water. Desalination, v. 322, p. 76-83, 2013. https://doi.org/10.1016/j.desal.2013.05.001 
LIU, H.; GU, T.; LV, Y.; ASIF, M.; XIONG, F.; ZHANG, G. et al. Corrosion inhibition and anti-bacterial efficacy of benzalkonium chloride in artificial $\mathrm{CO}_{2}$-saturated oilfield

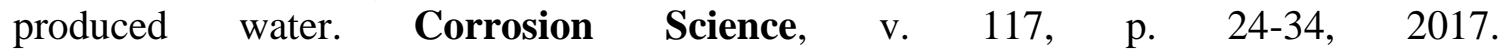
http://dx.doi.org/10.1016/j.corsci.2017.01.006

MIRZABEYGI, M.; ABBASNIA, A.; YOUZI, H.; ALIKHANI, M.; MAHVI, A. Evaluation of groundwater quality and assessment of scaling potential and corrosiveness of water supply networks, Iran. Research and Technology-AQUA, p. 1-10, 2017. https://doi.org10.2166/aqua.2017.128

OMAKA, O. N.; OFFOR, I. F.; ONWE, I. M. Hydrogeochemical attributes and ground water quality of Ngbo Community in Ohaukwu Area Council, Ebonyi State, Nigeria. Revista Ambiente \& Água, v. 10, n. 1, p. 35-47, 2015. http://dx.doi.org/10.4136/ambi-agua.1453

PENG, C.; FERGUSON, J.; KORSHIN, G. Effects of chloride, sulfate and natural organic matter (NOM) on the accumulation and release of trace-level inorganic contaminants from corroding iron. Water Research, v. 47, n. 14, p. 5257-5269, 2013. https://doi.org/10.1016/j.watres.2013.06.004

SORLINI, S.; BIASIBETTI, M.; ABBÀ, A.; COLLIVIGNARELli, M. C.; DAMIANI, S. Water Safety Plan for drinking water risk management: the case study of Mortara (Pavia, Italy). Revista Ambiente \& Água, v. 12, n. 4, p. 513-526, 2017. http://dx.doi.org/10.4136/ambi-agua.2102

TAVANPOUR, N.; NOSHADI, M.; TAVANPOUR, N. Scale Formation and Corrosion of Drinking Water Pipes: A Case Study of Drinking Water Distribution System of Shiraz City. Modern Applied Science, v. 10, n. 3, p. 166-177. 2016. http://dx.doi.org/10.5539/mas.v10n3p166

VAZDIRVANIDIS, A.; PANTAZOPOULOS, G.; RIKOS, A. Corrosion investigation of stainless steel water pump components. Engineering Failure Analysis, v. 82, p. 466-473, 2016. https://doi.org/10.1016/j.engfailanal.2016.09.009

WANG, Y.; CHENG, G.; WU, W.; QIAO, Q.; LI, Y.; LI, X. Effect of pH and chloride on the micro-mechanism of pitting corrosion for high strength pipeline steel in aerated $\mathrm{NaCl}$ solutions. Applied Surface Science, v. 349, p. 746-756, 2015. https://doi.org/10.1016/j.apsusc.2015.05.053

YANG, F.; SHI, B.; GU, J.; WANG, D.; YANG, M. Morphological and physicochemical characteristics of iron corrosion scales formed under different water source histories in a drinking water distribution system. Water Research, v. 46, n. 16, p. 5423-5433, 2012. https://doi.org/10.1016/j.watres.2012.07.031

YOUSEFI, M.; SALEH, H. N.; MAHVI, A. H.; ALIMOHAMMADI, M.; NABIZADEH, R.; MOHAMMADI,A. A. Data on corrosion and scaling potential of drinking water resources using stability indices in Jolfa, East Azerbaijan, Iran. Data Brief, v. 16, p. 724-731, 2018. https://doi.org/10.1016/j.dib.2017.11.099

ZHANG, X.; MI, Z.; WANG, Y.; LIU, S.; NIU, Z.; LU, P. et al. A red water occurrence in drinking water distribution systems caused by changes in water source in Beijing, China: mechanism analysis and control measures. Frontiers of Environmental Science \& Engineering, v. 8, n. 3, p. 417-426, 2014. https://doi.org/10.1007/s11783-013-0558-4 